\title{
When good vaccines go wild: Feral Orthopoxvirus in developing countries and beyond
}

\author{
Nissin Moussatché, ${ }^{1,2}$ Clarissa R. Damaso, ${ }^{2}$ and Grant McFadden ${ }^{1}$ \\ ${ }^{1}$ Dept. Molecular Genetics and Microbiology, University of Florida, Gainesville, FL 32610-0266, United States of America. \\ ${ }^{2}$ Instituto de Biofísica Carlos Chagas Filho, Universidade Federal do Rio de Janeiro, Rio de Janeiro, RJ, 21941-902, Brazil.
}

\begin{abstract}
The presence of zoonotic poxviruses in nature represents a potential human health risk that has to be re-evaluated by health authorities not only in developing countries, but also in many developed countries. For example, buffalopox virus infection remains to be a threat to humans and cattle in India, and monkeypox virus infection persists in several inhabited places in Africa and, more recently, in the USA. There are also a great number of zoonotic transmissions of cowpox virus from cats to humans in Europe. For almost a decade in Brazil, vaccinia-like viruses have been isolated from human and cattle infections. This review examines the ability of potentially pathogenic orthopoxviruses, including feral versions of vaccinia virus vaccine, to persist in nature and re-emerge for reasons we do not yet understand.

Key Words: Poxviridae, Buffalopox, Brazilian vaccinia-like virus, cowpox, monkeypox, vaccinia, variola, smallpox vaccine, zoonotic virus, orthopoxvirus in humans.
\end{abstract}

J Infect Developing Countries 2008; 2(3):156-173.

Received 12 March 2008 - Accepted 30 April 2008

Copyright (C 2008 Moussatché et al. This is an open access article distributed under the Creative Commons Attribution License, which permits unrestricted use, distribution, and reproduction in any medium, provided the original work is properly cited.

\section{The Poxviridae family: The viruses, the disease, the vaccine}

The Poxviridae family consists of a group of complex viruses with a double-stranded DNA genome, a characteristic brick-like morphology and a replication cycle that occurs solely in the cytoplasm of the cells [1]. The genome size of these viruses varies between 134 to $360 \mathrm{kDa}$ depending on the virus genus. The genomic DNA is packaged inside a biconcave core structure which is surrounded by symmetrical proteinaceous structures, called the "lateral bodies." The core and lateral bodies are collectively enclosed by a membrane to form the infectious mature virion. During viral replication a cascade of virus genes are expressed in a controlled fashion where each stage of the viral cycle depends on the completion of the previous phase. The coding capacity of different viruses in this family differs according to the individual members. As few as 131 and up to 328 putative ORFs have been assigned "in silico" for individual poxvirus members, but not all these assigned virus genes have been experimentally validated and their function assigned [2].
Viruses that comprise the Poxviridae family are able to infect almost all animal species [1,3]. This family is divided in two subfamilies, Chordopoxvirinae and Entomopoxvirinae, depending whether the infection occurs in vertebrate or invertebrate hosts. Viruses included in the Chordopoxvirinae family are subdivided in eight genera, of which half can infect humans and cause from mild to severe diseases that may culminate with the death of the host. Members of the Orthopoxvirus genus include those such as variola virus and monkeypox virus that most threaten human health.

The natural infection with most of the pathogenic poxviruses occurs through the respiratory tract, although many can also be inoculated via skin lesions [4]. The orthopoxviruses exhibit a tropism for epithelial cells and in general have the tendency to produce cutaneous lesions. In most of these cases, the lesions are characterized by progressive stages of macules, papules and vesicles. The initial opalescent vesicular fluid becomes opaque, turbid, and finally turns into a pustule. The absorption of the fluid promotes the formation of a scab and the healing 
of the lesion. Among the members of the orthopoxviruses, the most deadly virus for humans is variola major, the agent of smallpox, but this virus now is only known to exist in two declared World Health Organization (WHO) approved repositories at the Center for Disease Control (CDC), Atlanta, and Novosibirsk, Russia.

Vaccinia virus is the prototype member of the Orthopoxvirus genus and was the live vaccine agent used for the smallpox eradication campaign. During the last decade, several reviews have been written on different aspects of the poxvirus replicative cycle: reproduction [1]; transcription [5,6]; DNA replication [7]; morphogenesis [8]; proteolysis [9]; envelope formation [10]; entry [11]; tropism and immune evasion [12,13]. In this review, we will concentrate on the ability of some orthopoxviruses, including those that are likely to be escaped vaccinia vaccine strains, to persist in nature and re-emerge for no obvious reason.

The legacy of smallpox blends with world history because this disease has been known for more than 3,000 years $[4,14,15]$. For centuries, repeated epidemics have occurred across continents, devastating populations and changing the course of human history. It is believed that the smallpox pandemic started in Asia and spread throughout Europe and northern Africa in the last millennium. During the early years of circumnavigation by explorers from the Old World and their conquest of the New World, the disease extended its deadly path to other parts of Africa and to the American continents, becoming endemic in all the inhabitable places on Earth. The disease killed as many as $30 \%$ of those infected, and between $65-80 \%$ of survivors were marked with deep pitted scars (pockmarks), most prominently on the face.

It is important to point out the evolution of variants of variola major virus that were identified in the American continent and in Southern Africa $[4,15,16]$. Variola minor virus (V. minor), also called alastrim, was first reported at the end of the 19th century in Florida but it could have been imported from Africa. The less virulent V. minor virus spread out to different countries in the African and American continent and later reached Europe and Oceania. Although V. minor was considered an attenuated form of smallpox, the characteristics of the virus isolated in Brazil and in other parts of
Africa suggest separate origins of the viruses [1618].

No effective treatment for smallpox was ever achieved although several approaches to prevent the disease or limit the spread of the infection were proposed during the last few centuries $[4,14,15]$. The most common early preventative procedure was variolation, a technique that consists of inoculation in the skin or nasal passages with live virus obtained from pustules or scabs removed from patients recovering from smallpox. With this procedure the induced disease was less severe in people than when contracted naturally, for reasons that are still unexplained.

A breakthrough occurred in 1796 when Edward Jenner described the use of what was then called cowpox virus (but which may differ significantly from the orthopoxvirus we now designate with this name) to protect humans against smallpox [19]. Cows that were infected with this older "cowpox virus" exhibited lesions on the udder and teats that could be transmitted to the hands of milkmaids by contact. Humans, particularly cowmaids, infected with this zoonotic virus revealed lesions similar to those associated with smallpox, but which were localized to just the site of the inoculation and did not spread through the body. Furthermore, cowpox-inoculated milkers were resistant to natural smallpox infection and also to variolation. This observation was the first step in the development of a vaccination procedure that reversed the fate of those who came in contact with smallpox. Although cowpox has never been a frequent disease in animals, it is commonly accepted that the initial smallpox vaccine used by Jenner was derived from either an older version of a cowpox virus strain or another related orthopoxvirus that resided in a host species that has since become extinct. For example, another source of the smallpox vaccine virus likely to have been more widespread during this era was horsepox virus [20]. During the years of vaccination, the use of the live vaccine virus we now call vaccinia virus replaced the original cowpox virus, but the exact period in history that the change occurred is unknown. Today we know that vaccinia virus is genetically and biologically distinct from the poxviruses that we now call cowpox and horsepox viruses [21].

Vaccination using cowpox virus was much safer than variolation and did not cause the spread 
of the infection to unvaccinated people $[4,14,15]$. Therefore, this empirical practice was progressively utilized to protect the population, and supplanted variolation as the preventative method of choice to protect humans against smallpox. The new vaccination procedure, at that time two centuries ago, had no scientific explanation; it could sometimes cause serious side effects in some people, and sometimes the vaccine sample was contaminated with other pathogenic microorganisms [22-26]. These facts generated a controversy about the virtues of vaccination that lasted for more than a century [27]. Groups both in favor of and against the vaccination procedure presented their rationales to the various communities where it had been introduced. However, during the nineteenth century and the first half of the twentieth century, a remarkable decline was observed in the number of lethal smallpox cases in the world, which made even skeptics believe that vaccination was the best available mechanism to prevent the disease spread in the overall human population $[4,15,28]$.

\section{The early days of vaccination}

In the early 19th century, well-informed citizens became more receptive to Jenner's vaccination procedure $[14,15]$. This procedure rapidly reached several countries in Europe, crossed the Atlantic Ocean to the American continent, and later was adopted in some of the European colonies. One of the major problems during this "technology spread" was to maintain the vaccine virus active throughout transportation to distant regions of the world $[4,15,29]$. Poxviruses are fairly resistant to inactivation and most vaccine preparations could be preserved in absence of refrigeration for at least a short period of time, but after a long period the vaccine lost its effectiveness. Viral material freshly removed from the cow pustules was found to be more potent to protect the vaccinee than the virus that had been serially propagated through human arm-to-arm procedure ("humanized" or "Jennerian" vaccine). Nevertheless, it was easier to transport the "humanized" vaccine to new parts of the world [26]. However, a risk factor observed with the Jennerian vaccine was that the pus removed from the vaccination site on a human arm and inoculated into the next person could also transmit other unrelated diseases, such as syphilis and erysipelas [4].
The loss of potency was another factor of worry in the larger scale production of an effective vaccine. To restore its "virulence," the virus was re-inoculated into the cows and a new batch of effective vaccine was harvested from infected cow skin. However, this practice could lead to crosscontamination of cowpox with another virus known as pseudocowpox or paravaccinia (genus Parapoxvirus) that could also infect cattle and cause similar lesions on cow udders, but did not protect against smallpox [4]. Therefore, it was important to distinguish the "true" smallpox vaccine virus from the one that could not protect the vaccinee. At this time, it was also established that periodic revaccination was an important step to fully protect vaccinated people and prevent the spread of smallpox.

The first technical breakthrough that led to the future eradication of smallpox came with the development of the animal-based vaccine, instead of the humanized "Jennerian" vaccine, and the introduction of a preservation procedure that allowed live virus to be transported without losing its strength as a vaccine $[4,15,30]$. The animalbased vaccine preparations were more likely to be free from contamination with other human diseases, and this method rapidly spread to many countries by the end of the 19th century [22-25]. The use of the animal vaccine in most countries was associated with the establishment of vaccine production centers. The vaccine was initially clarified from scraped skin debris and later semipurified viruses were prepared for inoculation. The second breakthrough came with the preparation of freeze-dried stocks or glycerol-stored vaccines that were more stable for transportation. Finally, the presence of bacterial contaminants in the vaccine samples was still a great health safety concern. Some vaccine manufacturers kept their animals in poor hygienic conditions and, as a consequence, the harvested vaccine could be contaminated with a variety of bacteria that could, and did, harm the vaccinees.

Thus, vaccine viruses from different sources were used to produce the vaccine that was manufactured locally and these could vary dramatically in their potencies. Only in the beginning of the 20th century was the concept of quality control better understood and each nation then started developing their own guidelines and regulations for manufacturing their national 
vaccines [4,26]. A Smallpox and Vaccination Commission was created by the Health Organization of the League of Nations to create standards for vaccine production and later this task was incorporated into the new World Health Organization. The final standards and recommendations, set by $\mathrm{WHO}$, were implemented throughout the global Smallpox Eradication Campaign until the eradication of smallpox as an extant human disease in the 1970s.

\section{The smallpox eradication campaign}

During the first half of the 20th century, smallpox and alastrim were endemic in different parts of the world and in some places, such as central Africa, they co-existed [4]. In most European countries, where the vaccine program had been well implemented, smallpox cases were usually associated with immigration. V. minor virus was thus never established in the majority of the Old World countries because of the elevated immunological response of the population against smallpox. However, sporadic cases of V. minor were reported in Switzerland, Spain and England (after the virus was introduced from the USA following a Mormon conference in Nottingham) [15].

In the USA and UK, where the health services were very organized, smallpox outbreaks were controlled with selective vaccinations, whereas alastrim episodes received less attention from the authorities $[28,31,32]$. In the USA and Canada, V. minor outnumbered the cases of variola major but they were not always reported or noted [33].

In some African countries, the vaccination program was nonexistent and $\mathrm{V}$. minor replaced smallpox because of the sparse population in the affected regions. In India, where the population density was high but health services were deficient, variola major became epidemic because it could spread more efficiently and quickly than alastrim. On the other hand, Brazil was also a populous country with a health service more responsive than that in India, but less efficient than those in European countries and, as a consequence, the milder alastrim was able to establish in the population, virtually replacing variola major [4].

Compulsory vaccination, if applied in general, could have been a solution to prevent the spread of the disease much earlier than actually occurred $[4,31,34,35]$. This practice was introduced in the 20th century in several countries but it was not commonly implemented elsewhere. In Europe, for example, a mandatory vaccination law was applied only in Russia in 1919 by the new revolutionary government [4]. Later, this law in Russia was modified, and compulsory vaccination was required during infancy and revaccination required for all adolescents.

India was the only country in Asia that had a Vaccination Act $[4,15]$. This law required children to be vaccinated in the first 6 months after birth. However, this practice did not apply to all provinces. Furthermore, the Vaccination Act was imperfectly conceived and was not adequately enforced. By the middle of the 20th century, Madras was the only province in India where revaccination was made mandatory.

Most countries in Africa never did have a law that obligated their citizens to be vaccinated. The only exception was in Ethiopia when Emperor Menelik II issued an edict proclaiming vaccination to be mandatory. However, this decree was not well implemented and Ethiopia was one of the very last countries to have smallpox eradicated $[4,15]$.

In Canada and the USA, there was not a single uniform vaccination policy among the provinces or states [4,31]. Although Massachusetts had enacted mandatory school vaccination law, it was not enforced until a statewide outbreak occurred. It is of interest to note the reaction of the population and the health authorities in relation to the outbreaks of variola major and minor. During a V. minor epidemic, a few thousand people would generally seek out vaccination sites; but during a variola major outbreak hundreds of thousands of citizens would be vaccinated by the authorities [15]. Several states in the USA had in fact repealed laws that enforced mandatory vaccination, even for children, until the Supreme Court ruled that the public school authorities had the right to require vaccination for admission [34]. By the middle of the twentieth century, four US states had laws prohibiting mandatory vaccination; twenty-nine had no vaccination laws at all; six states were "pro-choice"; and ten had compulsory vaccination laws [25].

Laws that made smallpox vaccination mandatory were enacted in several countries in Latin America. In Mexico, Guatemala, Costa Rica, 
Dominican Republic, Haiti, Bolivia, Chile, Uruguay, and Argentina, mandatory vaccination became required for all infants and revaccination for early youth was also made compulsory [15]. However, in general, the laws were never rigorously imposed on the population. Highly populated port cities were preferential sites for smallpox epidemics, and several cities in Brazil could be included in this category. In the beginning of the 20th century, the Brazilian government reinstated the law of 1837 that made vaccination mandatory but this was never reinforced [36,37]. This act was not accepted by parts of the population, and weeklong riots occurred until the government revoked the law, took control of the situation and then restored the vaccination program $[38,39]$.

During the first 150 years after the introduction of vaccination, up to 50 million people were infected with variola virus each year [4]. With the vaccination program extended for an additional 15 years in the middle of the 20th century, the new smallpox cases were reduced to one fifth of that number. Many different strains of the vaccinia virus were used to produce the vaccine, but the actual origins of the seed stocks were usually nondocumented and probably some may have come from the same source. The Lister strain of vaccinia virus was used in most of the countries in the WHO eradication campaign but it sometimes was renamed for no particular reason. On the other hand, the NYCBH strain of vaccinia was used only in the American continent. The Paris strain of vaccinia virus was also widely used, but later it was replaced by other strains in most countries, although France, Turkey and Brazil continued to use it. Other vaccinia strains were regularly used, such as Temple of Heaven in China; Patwadangar in India; Bordeaux in Portugal and Mozambique; and Tashkent in Russia. Because some countries had more than one vaccine production site, sometimes more than one strain of vaccinia virus was being produced and used in the same population [4].

In 1966, the 19th World Health Assembly requested the Director-General of WHO to initiate an action to conduct a worldwide intensified smallpox eradication program. For the next eleven years, a true worldwide vaccination program was developed under strict supervision of World Health Organization, and the cases of variola major and minor were reduced progressively until the last natural case occurred in Somalia in 1977. A global certification of smallpox eradication was issued after an intense verification in all continents in December 1979 and subsequently endorsed by the World Health Assembly in 1980.

\section{Orthopoxviruses isolated from animals during the vaccination crusade}

The presence of apparently new poxviruses in animals has been reported in several countries after the smallpox vaccination was put into practice [4]. Because the original cowpox virus was isolated by Jenner in cows and later from milkmaids, all similar infections observed in cows were attributed, in general at the time, to be caused by the same cowpox virus and, later, by the actual vaccine virus [40].

In Europe, poxviruses isolated from animals were generally called cowpox virus by default or given a name following the host. In Holland, "cowpox virus" was more frequently isolated than in Britain, leading the authors to suggest that this virus was enzootic in cows particularly in that region [41].

In Copenhagen, a poxvirus was isolated from captive monkeys in 1958 and was named "monkeypox virus" [40]. Early surveys of monkey sera from different parts of the world did not reveal the presence of anti-poxvirus antibodies, and only in a later study were specific monkeypox antibodies found in a low percentage of wild monkeys tested $[42,43]$. It is also possible that in the first cases of monkeypox, the virus was actually transmitted to captive monkeys from a vaccinated member of staff. Only later was what we now call monkeypox virus definitively isolated as a new orthopoxvirus [44].

Orthopoxviruses were also isolated from other captive zoo animals, such as elephants and felines. A virus called elephantpox virus was first isolated in zoos and circuses in Germany. Early reports described this virus as a strain of vaccinia virus, but afterward other isolates showed that it was in fact different from either vaccinia virus or cowpox virus $[40,45,46]$. Orthopoxviruses were also isolated from animals in the Moscow zoo in 1973-74; most of the animals infected were from the family Felidae and the mortality rate was very high $[40,47,48]$. Although cowpox virus had never been isolated in the former USRR, the agent responsible for the infection was closely related to 
the European strains of cowpox virus. Immunological analysis could differentiate cowpox virus from the virus isolated from elephant, but not from the Moscow virus, suggesting that at least closely-related cowpox-like viruses were circulating in Europe [40].

The search for the agent that caused the death of the felines led to the zoo food supplier, a farm that provided live rats to feed the animals. Interestingly, the farm also had a spontaneous epizootic outbreak of poxvirus, and a virus was isolated from healthy and sick rats that could not be differentiated from the virus isolated from the afflicted felines [49].

The natural appearance of a poxvirus in farmed rodents led to a survey for the presence of the virus in wild rodents. The results revealed that nearly $15 \%$ of the animals tested positive for antipoxvirus antibody. Virus isolated from the wild animals could not be differentiated from the one isolated in the zoo and in the farm [4].

Poxviruses were also isolated from big gerbils (Rhombomys opimus) in Turkmenia, Central Asia. This virus resembled cowpox virus but was different from the mousepox virus, ectromelia [50]. Smallpox-like viruses were also isolated from camels in the former USSR, Iran, Iraq, Egypt, Somalia and Kenya [51-56]. The characteristics of the virus isolates as analyzed by pock formation and ceiling temperature in chorioallantoic membranes, hemagglutinin activity, and serology showed that the virus was quite similar to certain strains of variola and was classified as an orthopoxvirus (variola-vaccinia species).

In India, a virus from the orthopoxvirus genus was first isolated from water buffalo in 1934. Later, viruses with similar characteristics were re-isolated in different states of India and in other countries, including Pakistan, Egypt, Nepal and Bangladesh [57]. The virus, named buffalopox, infects various animals as well as humans. Initial reports suggested that buffalopox was related to vaccinia virus, but the level of similarity with vaccinia virus strains varied according to the buffalopox isolate [58-61]. Buffalopox virus became a very important zoonosis in several countries, but primarily in India, and we will discuss it separately below.

In the search for a possible animal repository for variola virus, a related virus strain - named white-wild or whitepox virus because of its properties on chicken chorioallantoic membranes
- was isolated from rodents in Equatorial Africa [42]. In the laboratory, the whitepox virus was isolated from hamsters infected with monkeypox virus but these were indistinguishable from variola virus [62]. Although it has been proposed that the origin of variola could be from monkeypox virus, the two viruses are genetically quite divergent, and it is also possible that the whitepox variant described in that report was instead monkeypox with a mutation/deletion in its genome.

In West Africa, an orthopoxvirus was isolated from a wild gerbil (Tatera kempii) and its biological features were different from ectromelia, cowpox, monkeypox, rabbitpox and vaccinia viruses [63]. Unfortunately most of these isolates have been lost over the years.

The smallpox vaccine virus was indigenous to the Old World and was brought to the American continents mainly in the arms of human vaccine carriers. Therefore, the appearance of a "spontaneous virus" infection in cows in America was probably due to the transmission from vaccinated people to animals or from cattle imported from Europe. Interestingly, a supposed case of "spontaneous cowpox virus" was described and isolated late in the 19th century by H.M. Alexander, a physician from Marietta County, PA, USA $[15,23]$. This virus was, for many years, the source of the vaccine fabricated by the Lancaster County Vaccine Farm, the predecessor of Wyeth Laboratories. However, it is not known exactly when this isolate was used to produce vaccine because the Wyeth smallpox vaccine was later made using the NYCBH strain as the seed.

Zoonotic poxvirus infections were reported in Latin America during the smallpox eradication campaign. In Uruguay, an outbreak of an orthopoxvirus occurred in unvaccinated people and spread to dairy cows [64]. In El Salvador, an outbreak of vaccinia virus occurred on a dairy farm and infected 22 workers and more than 400 cows [65].

In Brazil, several cases of orthopoxvirus infection in humans and dairy cows have been described since the beginning of the 19th century. One of the first reported isolates, in 1910, was the source of the vaccine prepared by the Instituto Vacinogênico (now Instituto Butantan) in São Paulo state, called the "Paulista G" seed [66]. In 1951 , so-called "cowpox viruses" were isolated in more than 100 counties in the state of São Paulo 
[66]. In the subsequent years, new isolates of orthopoxviruses infecting humans and dairy cows were reported in the states of São Paulo, Rio de Janeiro and Minas Gerais [67-72]. In some reports, the episodes were clearly related to the transmission of the smallpox vaccine from humans to the dairy herd. Similar cases frequently emerged for several decades until the early 1980s and re-emerged in 1999, and will be detailed below.

Other poxviruses were also isolated from different animals in Brazil, such as myxoma virus [73], Cotia virus [74], BeAn 58058 (BAV) [75] and orf virus[76]. Myxoma virus was isolated from rabbits; Cotia virus from sentinel mice; BAV from an Oryzomis rodents; and orf virus from goats. Recently, an unclassified poxvirus was isolated from Brazilian caimans [77]. BAV was later characterized as a vaccinia-like virus and orf virus as a Parapoxvirus; the classification of Cotia virus remains inconclusive. Since Cotia virus was isolated from sentinel mice, it was suggested that it could be classified as an arbovirus [74,78]. However, it is also possible that the virus was mechanically transmitted, similar to what occurs in nature during myxoma virus or capripox virus infections.

A cross-neutralization study revealed that Cotia virus was not able to neutralize vaccinia virus infection nor other poxvirus species tested [79]. Later, serological assays suggested that Cotia virus was similar to myxoma and fibroma viruses, but the restriction of the DNAs with different enzymes showed that each of these viruses had a unique DNA profile [80]. The restriction analysis of Cotia virus DNA showed that the virus resembles swinepox virus and the sequence of the thymidine kinase (TK) gene supports this conclusion. The predicted amino acid sequence of TK shared the highest identity scores with swinepox virus [81]. Although all the reports described above used virus derived from the same isolate (SPAn232), a later report also using SPAn232 suggested that Cotia virus is a vaccinialike virus [82].

\section{Persistence and re-emergence orthopoxviruses in nature}

The orthopoxviruses isolated until the early 1980s were identified through techniques that could not differentiate precisely members of distinct poxvirus genera or even between viruses of the same genus. Most of the differential approaches used at that time relied on a combination of biological tests, such as the ability of the virus to grow in chicken chorioallantoic membranes at different temperatures (i.e. ceiling temperature), the shape formation and color of the pock (white or hemorrhagic), hemagglutination inhibition assays, and the presence of neutralizing antibodies [83].

The first attempts to differentiate and classify the distinct Orthopoxvirus members using a molecular biology approach occurred at the end of the 1970s when poxvirus DNA was analyzed after digestion with restriction endonucleases [84]. Despite the size and complexity of the poxvirus genome, this procedure allowed the prediction of the genome size and the generation of a physical map of the viral DNA that differed among members of each genus. Later, with the advancement of newer techniques, such as PCR and DNA sequencing, it was possible to classify the poxviruses and differentiate the isolates in each genera with improved accuracy. The sequence of the entire virus genome, or some specific genes such as the hemagglutinin or the A-type inclusion, has been used to differentiate the Orthopoxvirus genus members [85-87]. Using specific primers for the hemagglutinin gene, it became possible to differentiate orthopoxviruses originated in the Old Word and the New World. With all this information, it is now possible to infer the phylogeny and better understand the evolution of the poxviruses in general.

During the first decade after the worldwide eradication of smallpox, there were reports on outbreaks of buffalopox in India [57,88-91], monkeypox in Africa [92-94], and cowpox in Europe [95-98]. In Kuwait, a poxvirus was isolated from a skin lesion on Rattus norvegicus and the tests indicated that it was a hemorrhagic poxvirus [99]. After 1999, outbreaks of vaccinia-like viruses began to be reported in Brazil [100-105].

In India, outbreaks of buffalopox in the Maharashtra State were reported from 1985 to 1987 [88]; from 1992 to 1996 [89]; and in 2003 [90]. The Hind III restriction profile of the DNA from thirteen buffalo isolates showed that one was clearly similar to vaccinia virus and the other twelve were undistinguished from each other. The twelve isolates showed some biological 
characteristics of the Hissar strain of buffalopox virus, but they had detectable differences in their DNA profiles [88].

In the 1990s, twenty-two virus samples were isolated after an outbreak of buffalopox in humans and buffalo. In humans, the lesions were mainly on the hands whereas in the animals the lesion were mostly on the teats and udders [89]. Children with no contact with the infected cattle presented pox lesions on different parts of the body, indicative of man-to-man transmission. Identification of the virus was conducted by classic biological approaches only, and no molecular characterization was reported.

The outbreak observed in 2003 caused a high morbidity in animals and also infected milkers and animal handlers [90]. PCR amplification and subsequent sequencing of a 552-base pair amplicon of the ATI gene revealed that the buffalopox isolate shared $99 \%$ sequence identity with vaccinia virus $W R$ and rabbitpox virus. The combined data reinforced previous suggestions that buffalopox virus is an escaped variant of vaccinia virus $[88,90]$.

As described above, the possible reservoirs of cowpox are wild rodents and the infection in such hosts varies seasonally [98,106-114]. This fact could explain the nature of the seasonal incidence of infection in accidental hosts, such as humans and domestic cats. In initial reports, the characterization was made only by biological studies, with no molecular analysis. Later, using molecular approaches, the identification and characterization of the virus became more accurate $[98,109,111-116]$. It is important to emphasize that in eczematous or immunosuppressed individuals, cowpox virus can cause a severe to fatal infection [95,117-119].

Cowpox virus was isolated from cats and humans in Norway and compared to two Swedish human isolates, and also to vaccinia virus WR and cowpox virus strain Brighton Red [120]. Although the six viruses presented some differences in the DNA restriction pattern, one of the Swedish isolates and the two Norwegian isolates had genomes larger than those of vaccinia virus, but smaller than those of cowpox Brighton Red. The analysis of the TK genes of the four viruses showed that the isolates from the same country had close or identical sequences. Furthermore, since all four isolates lacked a 72 base-pair region within the A-type inclusion that is present in the Brighton Red strain, it is possible that these isolates represent geographical strains of cowpox virus [121].

In Germany, several cases of humans infected with cowpox virus were reported and identified by molecular approaches [112]. Most of the reported cases had domestic cats as the vector $[97,116,119,122-124]$. One cowpox virus isolate was from an 11-year-old girl with an atopic predisposition. The patient had close contact with several cats from the neighborhood that could have probably transmitted the virus [116]. The identification and characterization of the virus was made by electron microscopy and virus isolation, and the classification was determined by polymerase chain reaction and restriction enzyme digestion of the PCR product.

In another report, a cowpox virus that caused a generalized infection with lethal outcome was isolated from an 18-year-old man, and by immunological and molecular biology approaches it was confirmed to have been acquired from a stray cat [119].

In another episode, three individuals presented skin lesions after being scratched by a cat that had an ulcerated lesion on its ear [123]. The woman presented with malaise, night sweats, painful right axillary lymph nodes and the appearance of an itchy nodule, surrounded by erythema that developed to a necrotic black scab. The other two patients had similar lesions but no malaise. The virus was isolated, the DNA purified, and an amplicon of the ATI gene was PCR-synthesized and analyzed by RFLP. The results showed that the infectious agent was cowpox virus but the strain type was not reported.

Although cowpox virus infection is an important zoonosis and it has been reported with regular frequency, there is a lack of information regarding the relationship between the various strains of this species and their relatedness to other orthopoxviruses. Phylogenetic analyses of sequenced members of the poxvirus family show that monkeypox virus, ectromelia virus and cowpox virus strain Brighton Red do not group closely with any other orthopoxvirus and vaccinia virus is most closely related to cowpox virus strain GRI-90 [125]. The authors suggest that these two cowpox virus strains have evolved from different 
ancestors and so the classification as two strains of the same species should be re-evaluated.

After the eradication of smallpox, monkeypox became the most important orthopoxvirus to infect humans [43,94,126-129]. Human cases of monkeypox, however, were rare events since only a few confirmed cases were reported during the 1970s. The disease was thought to occur infrequently in some villages in Cameroon, Côte d'Ivoire, Liberia, Nigeria, Sierra Leone, and the Democratic Republic of the Congo (DRC; former Zaire). Most of the cases are believed to have resulted from a zoonotic infection, although person-to-person spread appears to have occurred in some instances. Few cases were observed in the third or fourth generation of human-to-human transmission but after that the agent faded away. Evidence indicates that monkeypox virus is appreciably less transmissible between humans than variola virus. A case-fatality rate of $14 \%$ has been observed, but some human cases of monkeypox can be exceedingly mild or atypical and may easily remain undetected and unreported [130].

Interestingly, between 1981 and 1986, more than 400 human cases of human monkeypox virus infection were reported in Central and West Africa and more than 300 were identified just in the DRC $[129,131]$. The increase in cases during this period probably resulted from improved surveillance and case identification than from a true increase in incidence. The number of reported human monkeypox cases in West and Central Africa declined after 1986, and only 13 cases were reported in 1991. Phylogenetic inference analyses of the hemagglutinin ORF showed that monkeypox virus could be separated in two different clades, the West African and the Central African strains [131].

After a period of 5 years with no cases of monkeypox virus infection, an unusually large outbreak of human monkeypox was reported in August $1996[129,132,133]$. A total of 71 clinical cases of monkeypox, including 6 deaths, occurred in 13 villages in DRC. Different from earlier reports, a much higher number of secondary cases and a lower mortality rate were described [134]. DNA phylogenetic analysis of monkeypox virus isolates from this outbreak showed a close similarity to monkeypox viruses isolated in the region in 1970, 1977 and 1975 [132].
Outbreaks of monkeypox virus re-occurred in 2001 in the DRC, when thirty-one persons were infected and five fatal cases were reported [134]. Sixteen cases were confirmed to be monkeypox virus, including four fatalities. In two of the outbreaks, both monkeypox and varicella-zoster virus were isolated in seven cases, with one death confirmed. The other isolates were identified as varicella-zoster virus, which is characterized by a high rate of secondary transmission and a low mortality rate [92].

An outbreak that infected 11 youngsters less than 18 years old occurred in DRC in 2003 [135]. Six sequential and uninterrupted transmissions, from person-to-person, probably have occurred with an interval between 8 and 14 days from the first case until the last one. Not all the cases of monkeypox were confirmed by molecular, virologic, and serologic assays.

The infection of monkeypox virus in humans continued to occur in DRC, and the combined data from 2001 to 2004 reached a total of 2,734 suspected cases in all 11 provinces [131]. As described above, not all cases were confirmed as monkeypox virus, since varicella-zoster virus was also identified.

The first documented episode of human monkeypox outside the African continent occurred in 2003 in the Midwestern United States [92,136140]. The infection that occurred in the USA appeared to be milder than the disease described in the DRC. From a total of 81 identified cases, 32 had a laboratory confirmation; no human-to-human transmission was documented; and none resulted in death.

The probable source for the introduction of monkeypox virus into the USA was an international shipment of African rodents from Ghana to Texas. These mammals were rope squirrels (Funisciurus spp), tree squirrels (Heliosciurus spp), Gambian giant rats (Cricetomys spp), brushtail porcupines (Atherurus spp), dormice (Graphiurus spp), and striped mice (Hybomys spp). Not all the animals were confirmed to be a reservoir of monkeypox virus, but laboratory test reveal that some of the Gambian giant rats, rope squirrels, and dormice were infected with monkeypox virus. The Gambian giant rat may also have infected prairie dogs (Cynomys spp) in captivity $[92,138]$.

To further characterize the virus by molecular approaches, the hemagglutinin and A-type 
inclusion genes were PCR-amplified, followed by restriction-fragment-length polymorphism analysis. Identical restriction profiles were obtained from samples from the patients and a prairie dog, and the phylogenetic analysis showed that the virus from patients and the vector branched together [138]. Observations based on sequence phylogeny of 5 monkeypox virus genomes indicated that the USA isolates belonged to the West African clade, being distinct from the more pathogenic Congo Basin isolates [137].

Up to now it has been impossible to ascertain whether monkeypox virus has established an enzootic presence in the USA. It has been suggested that the virus cannot sustain itself permanently in communities by human-to-human transmission alone [141]. However, the possibility of reintroduction from an animal reservoir should be considered. If monkeypox virus could adapt to American native rodents such as rats, squirrels or prairie dogs, it will become a major public health concern regarding the potential for its establishment in novel reservoir species and ecosystems [78,92,138,140].

Starting in 1999 and continuing until today, more than 100 samples of vaccinia-like orthopoxviruses have been isolated from cattle and humans in dairy farms in Brazil [100-105,142]. This infection has become an important zoonotic disease, not only because of the health issues to humans and cattle (Figure 1), but also because it results in economic losses to the region.

The alignment of the sequences of the HA and SPI-3 genes from many of these isolates (Tables 1

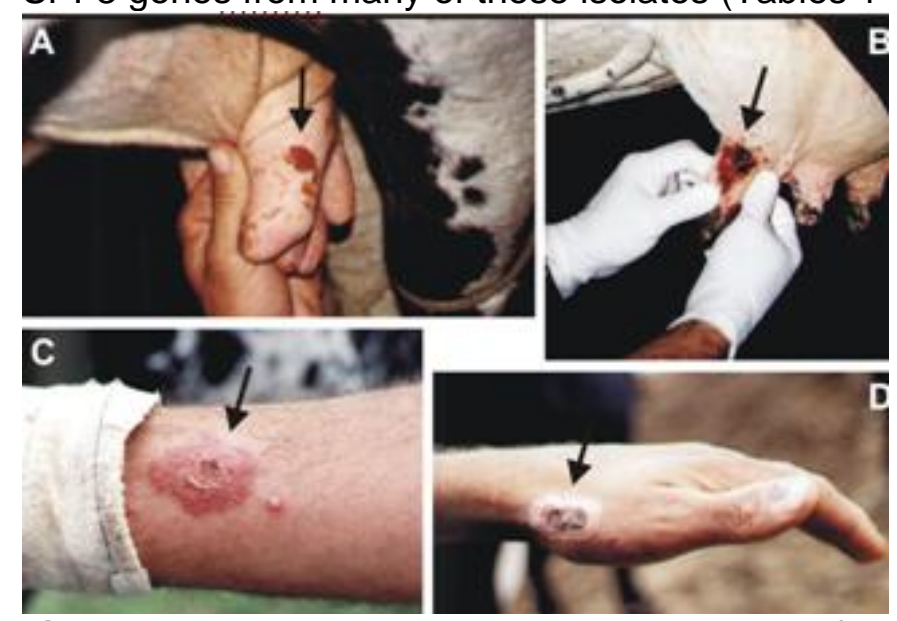

Figure 1. Lesions on dairy cattle and milkers after infection with VACV-like isolates. (A, B) - ulcerative lesions on teats of cows; (C, D) - lesions on forearm and hand of milkers. Arrows indicate the lesion areas. and 2) reveals two important sequence deletions in the virus isolated since 1999 with the sole exception of Guarani P1 virus [105]. The phylogenetic analysis of the viral HA genes showed that Guarani P1 branched separately from the other isolates, but together with the WR strain of vaccinia virus. Within this second group of Brazilian vaccinia-like viruses, we can also find the vaccinia virus (VACV) strain BAV, SPAn232 (SAV) and Belo Horizonte virus (BHV)[75,143,144]. Because BAV and SAV were isolated only once four decades ago, and BHV was isolated in 1993 in a constrained environment (from a mouse colony), there is no solid support for the proposed suggestion that these strains represent a second circulating group of vaccinia virus in Brazil $[105,144,145]$. Intriguingly, all the Brazilian viruses in the alleged group II are closely related to the laboratory strain WR.

The search for the parent virus strain that may have originated the recent isolates has been a great challenge. The phylogenetic analysis of the sequenced HA genes groups all the Brazilian isolates in the same sub-clade of vaccinia virus (Figure 2). Furthermore, with the exception of Guarani P1, all the Brazilian samples isolated during the vaccinia outbreaks present a six amino acid deletion between positions 252-257 in the HA gene that distinguish them from all other VACV strains and act as a signature for this group of viruses (Table 1). The VACV strains Len, Duke, LC16m8, LC16m0, Lister-Butantan and Malbran also have a five amino acid deletion between positions 247-251 that could be the characteristic of this group. The strain Lister-Butantan had also been used in Brazil as maintenance vaccination and the Malbran strain was used in Argentina during the eradication campaign [145,146]

Remarkably, the same signature in the HA gene was also observed in the Brazilian vaccinestrain of vaccinia virus (VACV-IOC), produced by the Instituto Oswaldo Cruz, Rio de Janeiro, Brazil, and used by the Brazilian government for systematic vaccination during the smallpox eradication campaign. Although VACV-IOC presents the HA signature characteristic of the Brazilian isolates, this virus merges into a different sub-clade in the phylogeny tree (Figure 2).

Another specific signature was found in one of the serine-protease inhibitor genes (VACWR033K2L-SPI-3) [145]. The Brazilian VACV isolated 
from outbreaks and sequenced, except for Guarani $\mathrm{P} 1$, present a five amino acid deletion between positions 327-331 not detected in any other vaccinia strain (Table 2). Coincidentally or not, VACV-IOC also presents the same deletion. Nevertheless, although the Brazilian isolates and the VACV-IOC share the same deletion signature, they do not merge in the same clade in the phylogenetic tree. In addition, Passatempo virus (PSTV), that also shares the signature, branches separately from the other isolates and VACV-IOC (Figure 3). The presence of specific deletions in at least two different genes may be taken as a strong suggestion that both VACV-IOC and the Brazilian isolates have derived from a common ancestor $[147,148]$. However, how close these viruses are related it is difficult to predict.

Some considerations should be evoked to understand the differences observed in the phylogeny trees and the sequence alignments. One characteristic of poxviruses is that they freely recombine their DNA molecule during the course of viral replication [149]. In this process, it has been proposed that cellular genes could be acquired or captured to confer selective advantages for virus-host interactions [150]. The traditional vaccines used since the early days of vaccination until the end of the smallpox eradication campaign were obtained from a genetically heterogeneous pool of virus stocks [151]. As best as we know, the VACV-IOC sample analyzed was always kept in a restricted environment of a vaccine production facility through all the years of the smallpox vaccination program. On the other hand, the Brazilian isolates appear to have escaped in a single event or in multiple events and probably adapted to a new host, until they re-emerged in man or cattle at least 25 years later. Thus, in these two different

Figure 2. Phylogenetic tree of the Orthopoxvirus genus based on the HA amino acid sequence. The amino acid sequence of the HA protein (VACV-Cop A56R ORF) of 47 orthopoxviruses were aligned by Clustal $X$ version 1.81 , using the default parameters, followed by visual inspection [152]. Phylogeny inference was performed using MEGA version 4 [153], opting for the neighborjoining method and JTT matrix-based model of substitution. Numbers indicate the percentage of bootstrap support from 1,000 replicates. Values $>50 \%$

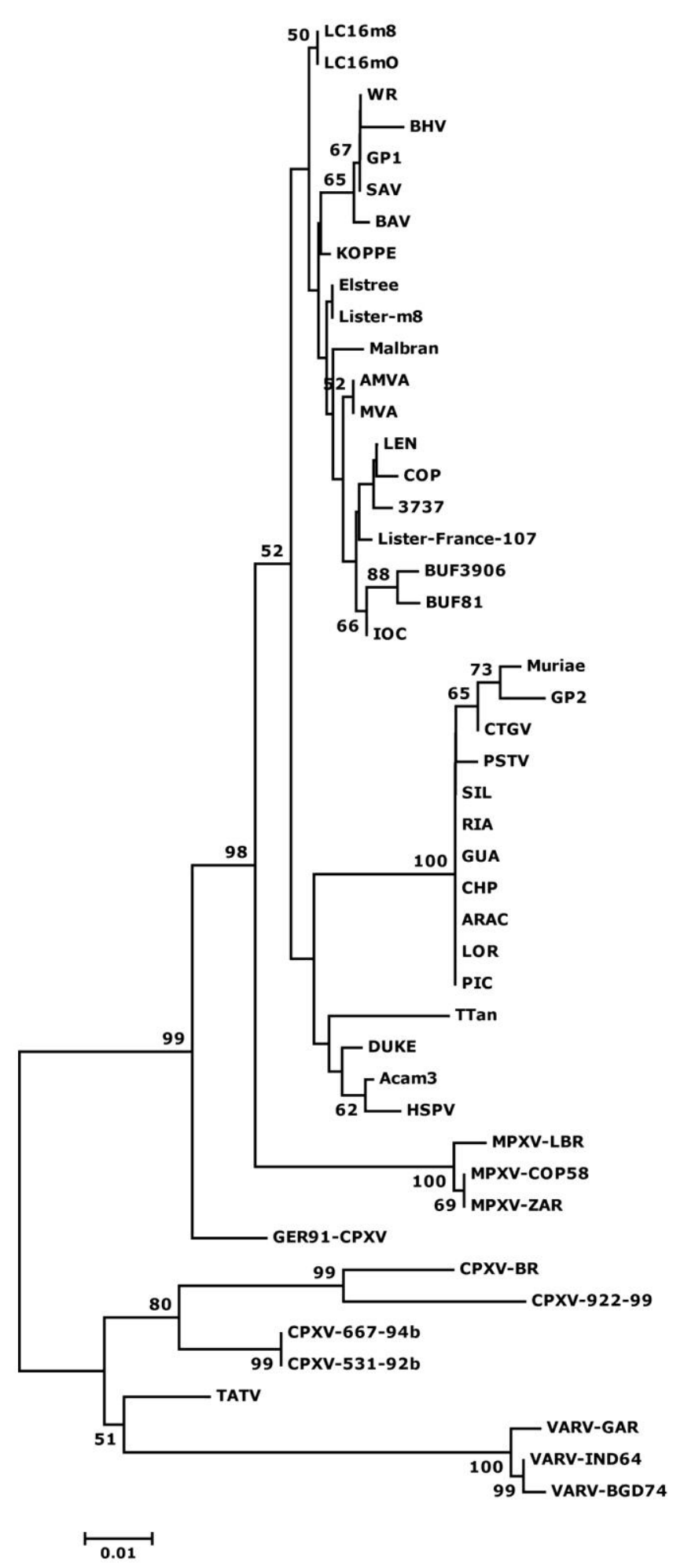

are shown. Analysis of the HA nucleotide sequences to infer neighbor-joining or most parsimonious trees supported this tree topology. 


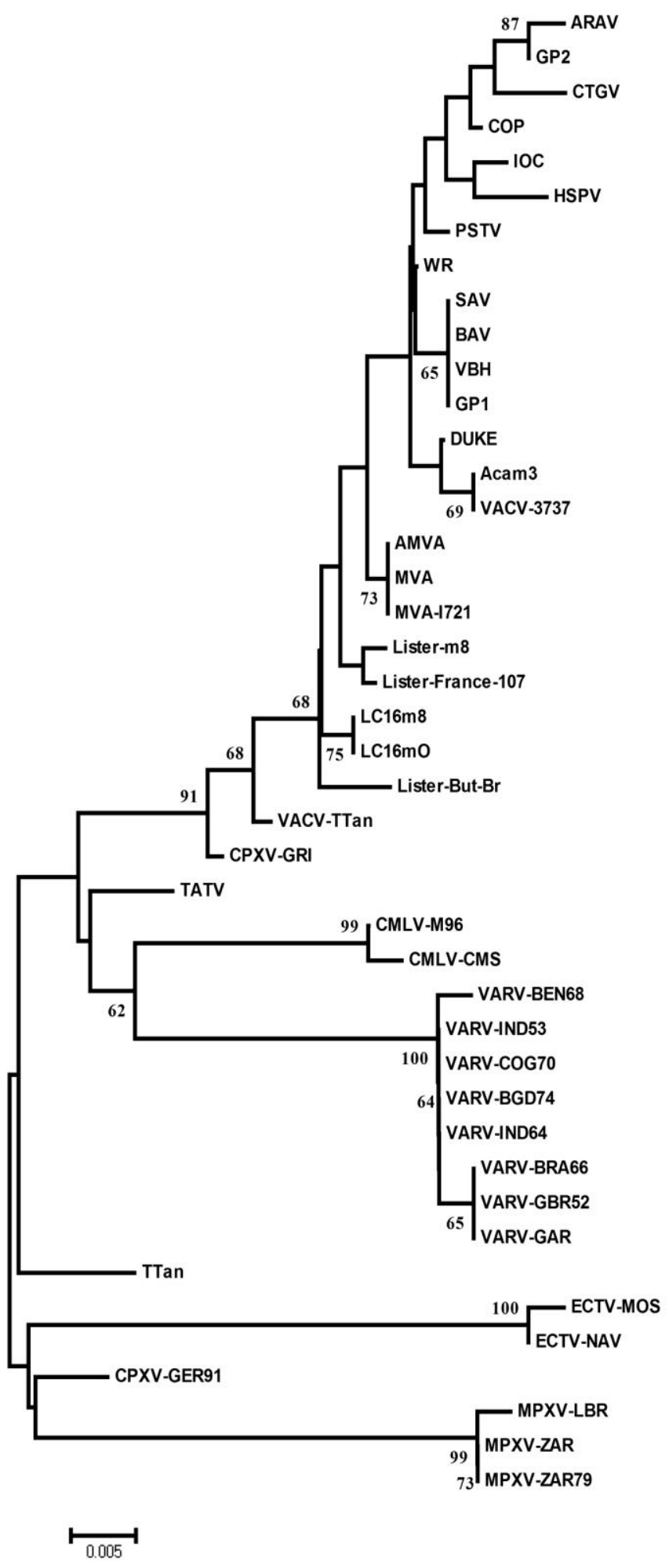

environments, the ancestor virus could have evolved in parallel but different orthopoxvirus genetic backgrounds.

\section{Final thoughts}

The presence of zoonotic poxviruses in nature is a potential human health risk that has to be reevaluated by health authorities in many countries. Because vaccinia virus has no known natural host, it was believed at the time of the vaccination program that the virus could not become established in hosts living freely in the local environment. However, during the years of vaccination, the vaccine virus was probably reisolated from the wild but was misidentified because of the lack of an appropriate tool to differentiate it from other orthopoxviruses. Vaccination was routinely conducted in the population and if the virus could find an appropriate permissive host, it could in fact adapt and persist in the new environment. This was likely the case of the Brazilian-like vaccinia viruses that have been isolated to date.

Cowpox virus infections in humans were also a rare event during the early years of vaccination, but for the last decades a great number of zoonotic episodes have been reported. Whether the cessation of smallpox vaccination has led to an increase in the number of cowpox virus infections is still a matter of consideration. However, we should also keep in our mind that cowpox virus has been frequently isolated from domestic animals in Europe and it could be a threat to immune-suppressed people; camelpox and buffalopox viruses are still important zoonotic agents in the Middle East and India; and finally monkeypox could again easily become a threat in the USA. After the monkeypox mini-epidemic incident in 2003, it is possible that this virus has also escaped and established in a new rodent environment in North America, and could reemerge in the near future to become a real medical threat to the unvaccinated population.

Figure 3. Phylogenetic tree of the Orthopoxvirus genus based on the SPI-3 amino acid sequence. The amino acid sequences of the SPI-3 protein (VACV-Cop K2L ORF) of 43 orthopoxviruses were aligned and phylogeny inference was performed as described in the legend of Figure 2. Numbers indicate the percentage of bootstrap support from 1,000 replicates. Values $>50 \%$ are shown. 
Table 1. Comparative analysis of the HA gene partial sequence, from amino acids 219 to 275 , of Brazilian vaccinialike isolates and the vaccinia strains COP, Lister, WR, Len, Duke, LC16m8, LC16m0; Malbran, Lister-Butantan, and IOC.

\begin{tabular}{|c|c|}
\hline VACV-Strain & VACWR181-A56R-Hemagglutinin - partial amino acid sequence \\
\hline $\mathrm{COP}$ & DHTVTDTVSYTTVSTSSGIVTTKSTTDDADLYDTYNDNDTVPSTTVGSSTTS ISNYK \\
\hline Lister & DHTVTDTVSYTTVSTSSGIVTTKSTTDDADLYDTYNDNDTVPPTTVGGSTTSISNYK \\
\hline WR & DHTVTDTVSYTTVSTSSGIVTTKSTTDDADLYDTYNDNDTVPPTTVGGSTTS ISNYK \\
\hline SAV & DHTVTDTVSYTTVSTSSGIVTTKSTTDDPDLYDTYNDNDTVPPTTVAGSTTSISNYK \\
\hline BAV & DHTVTDTVSYTTVSTSSGIVTTKSTTDDADLYDTYNDNDTVPPTTVGGSTTS ISNYK \\
\hline BHV & DHTVTDTVSYTTVSTSSGIVTTKSTTDDADLYDTYNDNDTVPPTTVGGSTTSISNYK \\
\hline GPV1 & DHTVTDTVSYTTVSTSSGIVTTKSTTDDADLYDTYNDNDTVPPTTVGGSTTSISNYK \\
\hline LEN & DHTVTDTVSYTTVSTSSGIVTTKSTTDD-----TYNDNDTVPSTTVGSSTTSISNYK \\
\hline DUKE & DHTVTDTVSYTTVSTSSGIVTTKSTTDD-----TYNDNDTVPPTTVGGSTTSISNYK \\
\hline $\mathrm{LC} 16 \mathrm{~m} 8$ & DHTVTDTVSYTTVSTSSGIVTTKSTTDD-----TYNDNDTVPPTTVGGSTTSISNYK \\
\hline $\mathrm{LC} 16 \mathrm{m0}$ & DHTVTDTVSYTTVSTSSGIVTTKSTTDD-----TYNDNDTVPPTTVGGSTTSISNYK \\
\hline Malbran & DHTVTDTVSYTTVSASSGIVTTKSTTDD-----TYNDNDTVPPTTVGGSTTSISNYK \\
\hline Lister-But-Br & DHTVTDTVSYTTVSTSSGIVTTKSTTDD-----TYNDNDTVPPTTVGGSTTSISNYK \\
\hline IOC & DHTVTDTVSYTTVSTSSGIVTTKSTTDDADLYD------TVPSTTVGGSTTSISNYK \\
\hline ARAV & DHTVTDTVSYTTVSTSSGIVTTKLTTDDADLYD------TVPPTTVGGSTTSISNYK \\
\hline PSTV & DHTVTDTVSYTTVSTSSGIVTTKLTTDDADLYD------TVPPTTVGGSTTSISNYK \\
\hline GPV2 & DHTVTDTVSYTTVSTSSGIVTTKLTTDDADLYD------TVPPTTVGGSTTSISNYK \\
\hline CTGV & DHTVTDTVSYTTVSTSSGIVTTKLTTDDADLYD------TVPPTTVGGSTTSISNYK \\
\hline $\mathrm{CHP}$ & DHTVTDTVSYTTVSTSSGIVTTKLTTDDADLYD------TVPPTTVGGSTTSISNYK \\
\hline GUA & DHTVTDTVSYTTVSTSSGIVTTKLTTDDADLYD------TVPPTTVGGSTTSISNYK \\
\hline $\mathrm{LOR}$ & DHTVTDTVSYTTVSTSSGIVTTKLTTDDADLYD------TVPPTTVGGSTTSISNYK \\
\hline PIC & DHTVTDTVSYTTVSTSSGIVTTKLTTDDADLYD------TVPPTTVGGSTTSISNYK \\
\hline RIA & DHTVTDTVSYTTVSTSSGIVTTKLTTDDADLYD------TVPPTTVGGSTTSISNYK \\
\hline SIL & DHTVTDTVSYTTVSTSSGIVTTKLTTDDADLYD------TVPPTTVGGSTTSISNYK \\
\hline
\end{tabular}

Table 2. Comparative analysis of the SPI 3 gene partial sequence, from amino acids 312 to 347 , of Brazilian vaccinia-like isolates and the vaccinia strains COP, Lister 045, Lister-Butantan, WR and IOC.

\begin{tabular}{ll}
\hline VACV Strain & VACWRO33/K2L/SPI-3 partial amino acid sequence \\
\hline COP & QNAKIDVDEQGTVAEASTIMVATARSSPEKLEFNT \\
Lister & QNAKIDVDEQGTVAEASTIMVATARSSPEKLEFNT \\
Lister-But- Br & QNAKIDVDEQGTVAEASTIMVATARSSPEKLEFNT \\
WR & QNAKIDVDEQGTVAEASTIMVATARSSPEKLEFNT \\
SAV & QNAKIDVDEQGTVAEASTIMVATARSSPEKLEFNT \\
BAV & QNAKIDVDEQGTVAEASTIMVATARSSPEKLEFNT \\
BHV & QNAKIDVDEQGTVAEASTIMVATARSSPEKLEFNT \\
GP1 & QNAKIDVDEQGTVAEASTIMVATARSSPEKLEFNT \\
ARAV & QNAKIDVDEQGTVAE-----VATARSSPEKLEFNT \\
CTGV & QNAKIDVDEQGTVAE-----VATARSSPEKLEFNT \\
GPV2 & QNAKIDVDEQGTVAE-----VATARSSPEKLEFNT \\
PSTV & QNAKIDVDEQGTVAE-----VATARSSPEKLEFNT \\
IOC & QNAKIDVDEQGTVAE-----VATARSSPEKLEFNT \\
\hline
\end{tabular}




\section{Acknowledgments}

Grant McFadden holds an International Scholarship of the Howard Hughes Medical Institute. Clarissa R. Damaso is a recipient of a Research Fellowship from Conselho Nacional de Desenvolvimento Científico e Tecnológico (CNPq), Brazil. This work was supported by National Institutes of Health grant R01 Al055560 to Nissin Moussatché.

\section{References}

1. Moss B (2007) Poxviridae: the viruses and their replication. In Knipe DM and Howley PM editors. Fields Virology Philadelphia Wolters Kluwer-Lippincott Williams and Wilkins. 2906-2945.

2. Poxvirus Bioinformatics Resource Center:www.poxvirus.org; Date accessed:2-12-2008.

3. Esposito JJ, Fenner F (2001) Poxviruses. In Knipe DM and Howley PM editors. Fields Virology Philadelphia Lippincott Williams \& Wilkins. 2885-2921.

4. Fenner F, Anderson DA, Arita I, Jezek Z, Ladnyi ID.(1988) Smallpox and Its Eradication, 1st edition Geneve. World Health Organisation. 1460p.

5. Broyles SS (2003) Vaccinia virus transcription. J Gen Virol 84: 2293-2303.

6. Condit RC, Niles EG (2002) Regulation of viral transcription elongation and termination during vaccinia virus infection. Biochim Biophys Acta 1577: 325-336.

7. Traktman P, Boyle K (2004) Methods for analysis of poxvirus DNA replication. Methods Mol Biol 269: 169186.

8. Condit RC, Moussatche N, Traktman P (2006) In a nutshell: structure and assembly of the vaccinia virion. Adv Virus Res 66: 31-124.

9. Byrd CM, Hruby DE (2006) Vaccinia virus proteolysis - a review. Rev Med Virol 16: 187-202.

10. Smith GL, Vanderplasschen A, Law M (2002) The formation and function of extracellular enveloped vaccinia virus. J Gen Virol 83: 2915-2931.

11. Moss B (2006) Poxvirus entry and membrane fusion. Virology 344: 48-54.

12. McFadden G (2005) Poxvirus tropism. Nat Rev Microbiol 3: 201-213.

13. Seet BT, Johnston JB, Brunetti CR, Barrett JW, Everett $\mathrm{H}$, Cameron C, Sypula J, Nazarian SH, Lucas A, McFadden G (2003) Poxviruses and immune evasion. Annu Rev Immunol 21: 377-423.

14. Behbehani AM (1983) The smallpox story: life and death of an old disease. Microbiol Rev 47: 455-509.

15. Hopkins D (1983) Princes and Peasants - Smallpox in History, 1st edition Chicago. The University of Chicago Press. 380p.

16. Shchelkunov SN, Totmenin AV, Loparev VN, Safronov PF, Gutorov VV, Chizhikov VE, Knight JC, Parsons JM, Massung RF, Esposito JJ (2000) Alastrim smallpox variola minor virus genome DNA sequences. Virology 266: 361-386.

17. Esposito JJ, Sammons SA, Frace AM, Osborne JD, Olsen-Rasmussen M, Zhang M, Govil D, Damon IK, Kline R, Laker M, Li Y, Smith GL, Meyer H, Leduc JW, Wohlhueter RM (2006) Genome sequence diversity and clues to the evolution of variola (smallpox) virus. Science 313: 807-812.

18. Li Y, Carroll DS, Gardner SN, Walsh MC, Vitalis EA, Damon IK (2007) On the origin of smallpox: correlating variola phylogenics with historical smallpox records. Proc Natl Acad Sci U S A 104: 15787-15792.

19. Jenner E.(1798) Enquiry into the Causes and Effects of Variolae Vaccinae, a Disease Discovered in some Western Countries of England, particularly Gloucestershire, and known by the Name of Cow Pox, London. Samson Low. 75p.

20. Baxby D (1999) Edward Jenner's Inquiry; a bicentenary analysis. Vaccine 17: 301-307.

21. Tulman ER, Delhon G, Afonso CL, Lu Z, Zsak L, Sandybaev NT, Kerembekova UZ, Zaitsev VL, Kutish GF, Rock DL (2006) Genome of horsepox virus. J Virol 80: 9244-9258.

22. Alexander HM (1894) Vaccine virus. The Medical and Surgical Report 70: 239-242.

23. Burr WH (1896) The Marietta vaccine farms. The Medical and Surgical Report 75: 488-491.

24. Clarke WB (1900) The pot calls the kettle black. The American Homeopathist 26: 163.

25. Lee B (1897) State Medicine in Pennsylvania. The Sanitarin 38: 16-19.

26. Parrino J, Graham BS (2006) Smallpox vaccines: Past, present, and future. J Allergy Clin Immunol 118: 13201326.

27. Wolfe RM, Sharp LK (2002) Anti-vaccinationists past and present. BMJ 325: 430-432.

28. Hardy A (1983) Smallpox in London: factors in the decline of the disease in the nineteenth century. Med Hist 27: 111-138.

29. Franco-Paredes C, Lammoglia L, Santos-Preciado J (2005) The Spanish royal philanthropic expedition to bring smallpox vaccination to the New World and Asia in the 19th century. Clin Infect Dis 41: 1285-1289.

30. Marquez M (1894) The animal vaccine - Why it should be preferred to human vaccine. Public Health Papers and Reports 19: 84-88.

31. Jackson CL (1969) State laws on compulsory immunization in the United States. Public Health Rep 84: 787-795.

32. Radetsky M (1999) Smallpox: a history of its rise and fall. Pediatr Infect Dis J 18: 85-93.

33. Belongia EA, Naleway AL (2003) Smallpox vaccine: the good, the bad, and the ugly. Clin Med Res 1: 87-92.

34. Colgrove J (2005) Science in a Democracy: The Contested Status of Vaccination in the Progressive Era and the 1920s. The History of Science Society 96: 167191.

35. Stewart AJ, Devlin PM (2006) The history of the smallpox vaccine. J Infect 52: 329-334.

36. Fernandes TM (1999) Vacina Antivariolica: Ciência, técnica e o poder dos homens-1808-1920, 103 p.p..

37. Teixeira LA, Almeida M (2003) [The beginnings of the smallpox vaccine in Sao Paulo: a little known story]. Hist Cienc Saude Manguinhos 10: 475-498.

38. Chalhoub S (1996) Cidade Febril - Cortiços e epidemias na Corte imperial, 1st edition São Paulo, SP, Brazil. Editora Schwarcz Ltda. 250 pp.. 
39. Needell JD (1987) The Revolta contra vacina of 1904: the revolt against "modernization" in belle epoque Rio de Janeiro. Hisp Am Hist Rev 67: 233-269.

40. Baxby D (1977) Poxvirus hosts and reservoirs. Brief review. Arch Virol 55: 169-179.

41. Baxby D (1975) Laboratory characteristics of British and Dutch strains of cowpox virus. Zentralbl Veterinarmed B 22: 480-487.

42. Arita I, Henderson DA (1976) Monkeypox and whitepox viruses in West and Central Africa. Bull World Health Organ 53: 347-353.

43. Arita I, Jezek Z, Khodakevich L, Ruti K (1985) Human monkeypox: a newly emerged orthopoxvirus zoonosis in the tropical rain forests of Africa. Am J Trop Med Hyg 34: 781-789.

44. Marennikova SS, Seluhina EM, Mal'ceva NN, Cimiskjan KL, Macevic GR (1972) Isolation and properties of the causal agent of a new variola-like disease (monkeypox) in man. Bull World Health Organ 46: 599-611.

45. Baxby D, Ghaboosi B (1977) Laboratory characteristics of poxviruses isolated from captive elephants in Germany. J Gen Virol 37: 407-414.

46. Gehring H, Mahnel H, Mayer H (1972) [Elephant pox]. Zentralbl Veterinarmed B 19: 258-261.

47. Marennikova SS, Maltseva NN, Korneeva VI, Garanina VM (1975) Pox infection in carnivora of the family Felidae. Acta Virol 19: 260.

48. Marennikova SS, Maltseva NN, Korneeva VI, Garanina N (1977) Outbreak of pox disease among carnivora (felidae) and edentata. J Infect Dis 135: 358-366.

49. Marennikova SS, Shelukhina EM (1976) White rats as source of pox infection in carnivora of the family Felidae. Acta Virol 20: 442.

50. Marennikova SS, Ladnyj ID, Ogorodinikova ZI, Shelukhina EM, Maltseva NN (1978) Identification and study of a poxvirus isolated from wild rodents in Turkmenia. Arch Virol 56: 7-14.

51. Baxby D (1972) Smallpox-like viruses from camels in Iran. Lancet 300: 1063-1065.

52. Tantawi HH, Saban MS, Reda IM, Dahaby HE (1974) Camel pox virus in Egypt. I-isolation and characterization. Bull Epizoot Dis Afr 22: 315-319.

53. Tantawi HH, El-Dahaby H, Fahmy LS (1978) Comparative studies on poxvirus strains isolated from camels. Acta Virol 22: 451-457.

54. Davies FG, Mungai JN, Shaw T (1975) Characteristics of a Kenyan camelpox virus. J Hyg (Lond) 75: 381-385.

55. Kriz B (1982) A study of camelpox in Somalia. J Comp Pathol 92: 1-8.

56. Falluji MM, Tantawi HH, Shony MO (1979) Isolation, identification and characterization of camelpox virus in Iraq. J Hyg (Lond) 83: 267-272.

57. Singh RK, Hosamani M, Balamurugan V, Bhanuprakash V, Rasool TJ, Yadav MP (2007) Buffalopox: an emerging and re-emerging zoonosis. Anim Health Res Rev 8: 105114.

58. Hill BJ, Baxby D, Douglas HW (1972) Microelectrophoresis of enzyme and chemically treated viruses and cores of vaccinia, buffalopox, variola and alastrim. J Gen Virol 16: 39-46.

59. Kataria RS, Singh IP (1970) Serological relationship of buffalopox virus to vaccinia and cowpox viruses. Acta Virol 14: 307-311.
60. Lal SM, Singh IP (1973) Buffalopox virus. (Preliminary report). Brief report. Arch Gesamte Virusforsch 40: 390391.

61. Lal SM, Singh IP (1973) Serological characterization of buffalopox virus. Arch Gesamte Virusforsch 43: 393-396.

62. Marennikova SS, Shelukhina EM (1978) Whitepox virus isolated from hamsters inoculated with monkeypox virus. Nature 276: 291-292.

63. Lourie B, Nakano JH, Kemp GE, Setzer HW (1975) Isolation of poxvirus from an African Rodent. J Infect Dis 132: 677-681.

64. Abebte Haedo F (1949) Epizootia de cowpox, en un ganado lechero, producudo por la inoculacion accidental de um hombre, recientemente sometido a la vacunacion antivariolica. Contaminacion consecutiva de todo el personal del estabelecimiento que no habia sido vacunado. Tratamiento por la fiebre artificial. Arch Urug Med 34: 252-259.

65. Lum GS, Soriano F, Trejos A, Llerena J (1967) Vaccinia epidemic and epizootic in El Salvador. Am J Trop Med Hyg 16: 332-338.

66. Vellini LL (1953) A variola bovina (cowpox) no estado de São Paulo e a sua transmissão ao homem. O Hospital 44: 107-112.

67. Angulo JJ, Salles-Gomes LF, Jordão FBM, Rabello SI, Amorosino A (1967) An epidemiological study of vaccinia in man. I. Effect of a mass vaccination in a pemphigus foliaceus hospital. O Hospital 72: 161-169.

68. Silva AS, Moraes LT (1960) Nota sobre a ocorrencia da variola bovina (cowpox) no Estado do Rio de Janeiro. I. Estudo da doença no município de Tres Rios. Veterinária 14: 31-35.

69. Mesquita JA, Schatzmayr HG (1969) Estudos Laboratoriais de Infecções humanas e de bovinos com o vírus do grupo pox. Rev Soc Bras Med Trop 3: 171-174.

70. Silva PA, Coelho HE, Viana FC, Lúcio WF, Ribeiro SCA, Oliveira PR (1986) [An outbreak of cowpox in the municipality of Prata, State of Minas Gerais -Brazil]. Arq Bras Med Vet Zoot 38: 323-330.

71. Mello D, Queiroz JC, Tomanik JP (1960) Variola bovina. Observações sobre casos animais e humanos ocorridos no Estado de São Paulo em 1959. O Biológico 26: 132137.

72. Reis R, Figueredo JB, Pacheco M (1970) [Cowpox Clinical aspects, characteristics of the virus and observation on vaccination.]. Arq Esc Veterinária 22: 213216.

73. Aragão HB (1927) Myxoma of Rabbits. Mem Inst Oswaldo Cruz 20: 237-247.

74. Lopes OS, LACERDA JP, FONSECA IE, CASTRO DP, FORATTINI OP, RABELLO EX (1965) Cotia Virus: A new agent isolated from sentinel mice in São Paulo, Brazil. Am J Trop Med Hyg 14: 156-157.

75. Fonseca FG, Lanna MC, Campos MA, Kitajima EW, Peres JN, Golgher RR, Ferreira PC, Kroon EG (1998) Morphological and molecular characterization of the poxvirus BeAn 58058. Arch Virol 143: 1171-1186.

76. Mazur C, Machado RD (1989) Detection of contagious pustular dermatitis virus of goats in a severe outbreak. Vet Rec 125: 419-420.

77. Ramos MC, Coutinho SD, Matushima ER, Sinhorini IL (2002) Poxvirus dermatitis outbreak in farmed Brazilian 
caimans (Caiman crocodilus yacare). Aust Vet J 80: 371372.

78. Regnery RL (2007) Poxviruses and the passive quest for novel hosts. Curr Top Microbiol Immunol 315: 345-361.

79. Ueda Y, Dumbell KR, Tsuruhara T, Tagaya I (1978) Studies on Cotia virus--an unclassified poxvirus. J Gen Virol 40: 263-276.

80. Esposito JJ, Palmer EL, Borden EC, Harrison AK, Obijeski JF, Murphy FA (1980) Studies on the poxvirus Cotia. J Gen Virol 47: 37-46.

81. Ueda Y, Morikawa S, Watanabe T (1995) Unclassified poxvirus: characterization and physical mapping of Cotia virus DNA and location of a sequence capable of encoding a thymidine kinase. Virology 210: 67-72.

82. Fonseca FG, Trindade GS, Silva RL, Bonjardim CA, Ferreira PC, Kroon EG (2002) Characterization of a vaccinia-like virus isolated in a Brazilian forest. J Gen Virol 83: 223-228.

83. Pfeffer M , Meyer H (2007) Poxvirus diagnostics. In Mercer AM, Schmidt A Weber O editors. Poxviruses Basel Birkhäuser Verlag. 355-373.

84. Wittek R, Menna A, Schumperli D, Stoffel S, Muller HK, Wyler R (1977) HindIII and Sst I restriction sites mapped on rabbit poxvirus and vaccinia virus DNA. J Virol 23: 669-678.

85. Meyer H, Ropp SL, Esposito JJ (1997) Gene for A-type inclusion body protein is useful for a polymerase chain reaction assay to differentiate orthopoxviruses. J Virol Methods 64: 217-221.

86. Meyer H, Damon IK, Esposito JJ (2004) Orthopoxvirus diagnostics. Methods Mol Biol 269: 119-134.

87. Ropp SL, Jin Q, Knight JC, Massung RF, Esposito JJ (1995) PCR strategy for identification and differentiation of small pox and other orthopoxviruses. J Clin Microbiol 33: 2069-2076.

88. Dumbell K, Richardson M (1993) Virological investigations of specimens from buffaloes affected by buffalopox in Maharashtra State, India between 1985 and 1987. Arch Virol 128: 257-267.

89. Kolhapure RM, Deolankar RP, Tupe CD, Raut CG, Basu A, Dama BM, Pawar SD, Joshi MV, Padbidri VS, Goverdhan MK, Banerjee K (1997) Investigation of buffalopox outbreaks in Maharashtra State during 19921996. Indian J Med Res 106: 441-446.

90. Singh RK, Hosamani M, Balamurugan V, Satheesh CC, Shingal KR, Tatwarti SB, Bambal RG, Ramteke V, Yadav MP (2006) An outbreak of buffalopox in buffalo (Bubalus bubalis) dairy herds in Aurangabad, India. Rev Sci Tech 25: 981-987.

91. Singh RK, Hosamani M, Balamurugan V, Satheesh CC, Rasool TJ, Yadav MP (2006) Comparative sequence analysis of envelope protein genes of Indian buffalopox virus isolates. Arch Virol 151: 1995-2005.

92. Di Giulio DB, Eckburg PB (2004) Human monkeypox: an emerging zoonosis. Lancet Infect Dis 4: 15-25.

93. Dumbell KR, Archard LC (1980) Comparison of white pock (h) mutants of monkeypox virus with parental monkeypox and with variola-like viruses isolated from animals. Nature 286: 29-32.

94. Jezek Z, Marennikova SS, Mutumbo M, Nakano JH, Paluku KM, Szczeniowski M (1986) Human monkeypox: a study of 2,510 contacts of 214 patients. J Infect Dis 154: 551-555.
95. Baxby D, Bennett M, Getty B (1994) Human cowpox 1969-93: a review based on 54 cases. Br J Dermatol 131: 598-607.

96. Baxby D, Bennett M (1997) Cowpox: a re-evaluation of the risks of human cowpox based on new epidemiological information. Arch Virol Suppl 13: 1-12.

97. Schulze C, Alex M, Schirrmeier H, Hlinak A, Engelhardt A, Koschinski B, Beyreiss B, Hoffmann M, Czerny CP (2007) Generalized fatal Cowpox virus infection in a cat with transmission to a human contact case. Zoonoses Public Health 54: 31-37.

98. Meyer H, Schay C, Mahnel H, Pfeffer M (1999) Characterization of orthopoxviruses isolated from man and animals in Germany. Arch Virol 144: 491-501.

99. Tantawi HH, Zaghloul TM, Zakaria M (1983) Poxvirus infection in a rat (Rattus norvegicus) in Kuwait. Int $\mathrm{J}$ Zoonoses 10: 28-32.

100.Damaso CR, Esposito JJ, Condit RC, Moussatche N (2000) An emergent poxvirus from humans and cattle in Rio de Janeiro State: Cantagalo virus may derive from Brazilian smallpox vaccine. Virology 277: 439-449.

101. Trindade GS, da Fonseca FG, Marques JT, Nogueira ML, Mendes LC, Borges AS, Peiro JR, Pituco EM, Bonjardim CA, Ferreira PC, Kroon EG (2003) Aracatuba virus: a vaccinialike virus associated with infection in humans and cattle. Emerg Infect Dis 9: 155-160.

102. Leite JA, Drumond BP, Trindade GS, Lobato ZI, da Fonseca FG, dos SJ, Madureira MC, Guedes MI, Ferreira JM, Bonjardim CA, Ferreira PC, Kroon EG (2005) Passatempo virus, a vaccinia virus strain, Brazil. Emerg Infect Dis 11: 1935-1938.

103. Nagasse-Sugahara TK, Kisielius JJ, Ueda-Ito M, Curti SP, Figueiredo CA, Cruz AS, Silva MM, Ramos CH, Silva MC, Sakurai T, Salles-Gomes LF (2004) Human vaccinia-like virus outbreaks in Sao Paulo and Goias States, Brazil: virus detection, isolation and identification. Rev Inst Med Trop Sao Paulo 46: 315-322.

104. Schatzmayr HG, Lemos ER, Mazur C, Schubach A, Majerowicz S, Rozental T, Schubach TM, Bustamante MC, Barth OM (2000) Detection of poxvirus in cattle associated with human cases in the State of Rio de Janeiro: preliminary report. Mem Inst Oswaldo Cruz 95: 625-627.

105. Trindade GS, Lobato ZI, Drumond BP, Leite JA, Trigueiro RC, Guedes MI, da Fonseca FG, dos S, Jr., Bonjardim CA, Ferreira PC, Kroon EG (2006) Short report: Isolation of two vaccinia virus strains from a single bovine vaccinia outbreak in rural area from Brazil: Implications on the emergence of zoonotic orthopoxviruses. Am J Trop Med Hyg 75: 486-490.

106. Bennett M, Crouch AJ, Begon M, Duffy B, Feore S, Gaskell RM, Kelly DF, McCracken CM, Vicary L, Baxby D (1997) Cowpox in British voles and mice. J Comp Pathol 116: 35-44.

107. Bennett M, Gaskell RM, Gaskell CJ, Baxby D, Kelly DF (1989) Studies on poxvirus infection in cats. Arch Virol 104: 19-33.

108. Chantrey J, Meyer H, Baxby D, Begon M, Bown KJ, Hazel SM, Jones T, Montgomery WI, Bennett M (1999) Cowpox: reservoir hosts and geographic range. Epidemiol Infect 122: 455-460.

109. Crouch AC, Baxby D, McCracken CM, Gaskell RM, Bennett M (1995) Serological evidence for the reservoir 
hosts of cowpox virus in British wildlife. Epidemiol Infect 115: 185-191.

110. Gaskell RM, Gaskell CJ, Evans RJ, Dennis PE, Bennett AM, Udall ND, Voyle C, Hill TJ (1983) Natural and experimental pox virus infection in the domestic cat. Vet Rec 112: 164-170.

111. Martland MF, Poulton GJ, Done RA (1985) Three cases of cowpox infection of domestic cats. Vet Rec 117: 231233.

112. Meyer $H$, Neubauer $H$, Pfeffer $M$ (2002) Amplification of 'variola virus-specific' sequences in German cowpox virus isolates. J Vet Med B Infect Dis Vet Public Health 49: 1719.

113. Naidoo J, Baxby D, Bennett M, Gaskell RM, Gaskell CJ (1992) Characterization of orthopoxviruses isolated from feline infections in Britain. Arch Virol 125: 261-272.

114. Pahlitzsch $R$, Hammarin AL, Widell A (9-15-2006) A case of facial cellulitis and necrotizing lymphadenitis due to cowpox virus infection. Clin Infect Dis 43: 737-742.

115. Schupp P, Pfeffer M, Meyer H, Burck G, Kolmel K, Neumann C (2001) Cowpox virus in a 12-year-old boy: rapid identification by an orthopoxvirus-specific polymerase chain reaction. Br J Dermatol 145: 146-150.

116. Wienecke R, Wolff $H$, Schaller M, Meyer H, Plewig G (2000) Cowpox virus infection in an 11-year-old girl. J Am Acad Dermatol 42: 892-894.

117. Blackford S, Roberts DL, Thomas PD (1993) Cowpox infection causing a generalized eruption in a patient with atopic dermatitis. Br J Dermatol 129: 628-629.

118. Eis-Hubinger AM, Gerritzen A, Schneweis KE, Pfeiff B, Pullmann H, Mayr A, Czerny CP (1990) Fatal cowpox-like virus infection transmitted by cat. Lancet 336: 880.

119. Czerny CP, Zeller-Lue C, Eis-Hubinger AM, Kaaden OR, Meyer H (1997) Characterization of a cowpox-like orthopox virus which had caused a lethal infection in man. Arch Virol Suppl 13: 13-24.

120. Tryland M, Sandvik T, Hansen H, Haukenes G, Holtet L, Bennett M, Mehl R, Moens U, Olsvik O, Traavik T (1998) Characteristics of four cowpox virus isolates from Norway and Sweden. APMIS 106: 623-635.

121. Hansen H, Sandvik T, Tryland M, Olsvik O, Traavik T (1999) Comparison of thymidine kinase and A-type inclusion protein gene sequences from Norwegian and Swedish cowpox virus isolates. APMIS 107: 667-675.

122. Stolz W, Gotz A, Thomas P, Ruzicka T, Suss R, Landthaler M, Mahnel H, Czerny CP (1996) Characteristic but unfamiliar--the cowpox infection, transmitted by a domestic cat. Dermatology 193: 140143.

123. Coras B, Essbauer S, Pfeffer M, Meyer H, Schroder J, Stolz W, Landthaler M, Vogt T (2005) Cowpox and a cat. Lancet 365: 446.

124. Schaudien D, Meyer $H$, Grunwald $D$, Janssen $H$, Wohlsein P (2007) Concurrent infection of a cat with cowpox virus and feline parvovirus. J Comp Pathol 137: 151-154.

125. Gubser C, Hue S, Kellam P, Smith GL (2004) Poxvirus genomes: a phylogenetic analysis. J Gen Virol 85: 105117.

126. Fine PE, Jezek Z, Grab B, Dixon H (1988) The transmission potential of monkeypox virus in human populations. Int J Epidemiol 17: 643-650.
127.Jezek Z, Gromyko Al, Szczeniowski MV (1983) Human monkeypox. J Hyg Epidemiol Microbiol Immunol 27: 1328.

128. Jezek Z, Szczeniowski M, Paluku KM, Mutombo M (1987) Human monkeypox: clinical features of 282 patients. J Infect Dis 156: 293-298.

129. Heymann DL, Szczeniowski M, Esteves K (1998) Reemergence of monkeypox in Africa: a review of the past six years. Br Med Bull 54: 693-702.

130.Janseghers L, Matamba M, Colaert J, Vandepitte J, Desmyter J (1984) Fatal monkeypox in a child in Kikwit, Zaire. Ann Soc Belg Med Trop 64: 295-298.

131. Rimoin AW, Kisalu N, Kebela-llunga B, Mukaba T, Wright LL, Formenty $\mathrm{P}$, Wolfe ND, Shongo RL, Tshioko F, Okitolonda E, Muyembe JJ, Ryder RW, Meyer H (2007) Endemic human monkeypox, Democratic Republic of Congo, 2001-2004. Emerg Infect Dis 13: 934-937.

132. Mukinda VB, Mwema G, Kilundu M, Heymann DL, Khan AS, Esposito JJ (1997) Re-emergence of human monkeypox in Zaire in 1996. Monkeypox Epidemiologic Working Group. Lancet 349: 1449-1450.

133. Mwanbal PT, Tshioko KF, Moudi A, Mukinda V, Mwema GN, Messinger $D$, Okito $L$, Barakymfyte $D$, Malfait $P$, Pebody R, Szczeniowski M, Esteves K, Heymann D, Hutin Y, Williams RJ, Khan AS, Esposito JJ (1997) Human monkeypox in Kasai Oriental, Zaire (1996-1997). Euro Surveill 2: 33-35.

134. Meyer H, Perrichot M, Stemmler M, Emmerich P, Schmitz H, Varaine F, Shungu R, Tshioko F, Formenty P (2002) Outbreaks of disease suspected of being due to human monkeypox virus infection in the Democratic Republic of Congo in 2001. J Clin Microbiol 40: 2919-2921.

135. Learned LA, Reynolds MG, Wassa DW, Li Y, Olson VA, Karem K, Stempora LL, Braden ZH, Kline R, Likos A, Libama $F$, Moudzeo $H$, Bolanda JD, Tarangonia $P$, Boumandoki $\mathrm{P}$, Formenty $\mathrm{P}$, Harvey JM, Damon IK (2005) Extended interhuman transmission of monkeypox in a hospital community in the Republic of the Congo, 2003. Am J Trop Med Hyg 73: 428-434.

136. Ligon BL (2004) Monkeypox: a review of the history and emergence in the Western hemisphere. Semin Pediatr Infect Dis 15: 280-287.

137. Likos AM, Sammons SA, Olson VA, Frace AM, Li Y, Olsen-Rasmussen M, Davidson W, Galloway R, Khristova ML, Reynolds MG, Zhao H, Carroll DS, Curns A, Formenty P, Esposito JJ, Regnery RL, Damon IK (2005) A tale of two clades: monkeypox viruses. J Gen Virol 86: 2661-2672.

138. Reed KD, Melski JW, Graham MB, Regnery RL, Sotir MJ, Wegner MV, Kazmierczak JJ, Stratman EJ, Li Y, Fairley JA, Swain GR, Olson VA, Sargent EK, Kehl SC, Frace MA, Kline R, Foldy SL, Davis JP, Damon IK (2004) The detection of monkeypox in humans in the Western Hemisphere. N Engl J Med 350: 342-350.

139. Sejvar JJ, Chowdary Y, Schomogyi M, Stevens J, Patel J, Karem K, Fischer M, Kuehnert MJ, Zaki SR, Paddock CD, Guarner J, Shieh WJ, Patton JL, Bernard N, Li Y, Olson VA, Kline RL, Loparev VN, Schmid DS, Beard B, Regnery RR, Damon IK (2004) Human monkeypox infection: a family cluster in the midwestern United States. J Infect Dis 190: 1833-1840.

140. Hutson CL, Lee KN, Abel J, Carroll DS, Montgomery JM, Olson VA, Li Y, Davidson W, Hughes C, Dillon M, 
Spurlock P, Kazmierczak JJ, Austin C, Miser L, Sorhage FE, Howell J, Davis JP, Reynolds MG, Braden Z, Karem KL, Damon IK, Regnery RL (2007) Monkeypox zoonotic associations: insights from laboratory evaluation of animals associated with the multi-state US outbreak. Am J Trop Med Hyg 76: 757-768.

141. Jezek Z, Grab B, Dixon H (1987) Stochastic model for interhuman spread of monkeypox. Am J Epidemiol 126: 1082-1092.

142. Damaso CR, Reis SA, Jesus DM, Lima PS, Moussatche $\mathrm{N}$ (2007) A PCR-based assay for detection of emerging vaccinia-like viruses isolated in Brazil. Diagn Microbiol Infect Dis 57: 39-46.

143. Trindade GS, da Fonseca FG, Marques JT, Diniz S, Leite JA, De BS, Van der PY, Bonjardim CA, Ferreira PC, Kroon EG (2004) Belo Horizonte virus: a vaccinia-like virus lacking the A-type inclusion body gene isolated from infected mice. J Gen Virol 85: 2015-2021.

144. Trindade GS, Emerson GL, Carroll DS, Kroon EG, Damon IK (2007) Brazilian vaccinia viruses and their origins. Emerg Infect Dis 13: 965-972.

145. Drumond BP, Leite JA, da Fonseca FG, Bonjardim CA, Ferreira PC, Kroon EG (2007) Brazilian Vaccinia virus strains are genetically divergent and differ from the Lister vaccine strain. Microbes Infect

146.Lewis A, Bok K, Perez O, DeFillippo J, Paolazzi C, Gomez JA (2005) Characterization of a vaccinia virus strain used to produce smallpox vaccine in Argentina between 1937 and 1970. Arch Virol 150: 1485-1491.

147. Griffiths E, Gupta RS (2004) Signature sequences in diverse proteins provide evidence for the late divergence of the Order Aquificales. Int Microbiol 7: 41-52.

148. Gupta RS (1998) Protein phylogenies and signature sequences: A reappraisal of evolutionary relationships among archaebacteria, eubacteria, and eukaryotes. Microbiol Mol Biol Rev 62: 1435-1491.

149. Shchelkunov SN (2005) Molecular Evoluton of Orthopoxviruses. In Shchelkunov SN, Marennikova SS, and Moyer RW editors. Orthopoxviruses pathogenic for humans NY Springer. 249-301.

150.Bugert JJ, Darai G (2000) Poxvirus homologues of cellular genes. Virus Genes 21: 111-133.

151. Osborne JD, Da SM, Frace AM, Sammons SA, OlsenRasmussen M, Upton C, Buller RM, Chen N, Feng Z, Roper RL, Liu J, Pougatcheva S, Chen W, Wohlhueter RM, Esposito JJ (2007) Genomic differences of Vaccinia virus clones from Dryvax smallpox vaccine: the Dryvaxlike ACAM2000 and the mouse neurovirulent Clone-3. Vaccine 25: 8807-8832.
152. Thompson JD, Gibson TJ, Plewniak F, Jeanmougin F, Higgins DG (1997) The CLUSTAL_X windows interface: flexible strategies for multiple sequence alignment aided by quality analysis tools. Nucleic Acids Res 25: 48764882.

153. Tamura K, Dudley J, Nei M, Kumar S (2007) MEGA4: Molecular Evolutionary Genetics Analysis (MEGA) software version 4.0. Mol Biol Evol 24: 1596-1599.

Corresponding Author: Nissin Moussatché, Dept. Molecular Genetics and Microbiology, PO Box 100266, University of Florida, Gainesville, FL 32610, USA. Phone: +1 352-392-3093, Fax: +1 352-392-3133, Email: nissin@ufl.edu

Conflict of interest: No conflict of interest is declared.

\section{Appendix}

Gene bank access number used to construct the phylogeny trees and tables:

For the VACWR181-A56R-Hemagglutinin gene: Vaccinia virus strains: ARAV (AY523994); BAV (DQ206442); GP1V (DQ206436); GP2V (DQ206437); PSTV (DQ070848); SAV (DQ222922); VBH (DQ206435); CTGV (AF229247); IOC (AF229248); SIL (DQ810277); RIA (DQ810280); GUA (DQ810279); CHP (DQ810278); LOR (DQ810281); PIC (DQ810276); Len (AF375123); Koppe (AF375122. Buffalopox virus strains: BFL-81(AF375078); BFL-3906 (AF375077). Cowpox virus: CPXV-641-94b (AF377882); CPXV-531-92b (AF377880). Horsepox virus: HSPV (DQ792504). Monkeypox virus: MKPV-COP58 (AY753185)

For the VACWR033/K2L/ SPI-3 gene: Vaccinia virus strains: ARAV (EF175987); BAV (EF175990); GP1V (EF175991); GP2V (EF175988); PSTV (EF175989); SAV (EF175992); VBH (EF175993); CTGV (EU528619); IOC (EU 528618); Lister-BUT-BR (EF175994). Ectromelia virus: ECTV-MOS (AF012825); ECTV-NAV (NC004105). Camelpox virus: CMLV-CMS (AY009089); CMLV-M96 (AF438165). Variola virus: VARV -BRA66 (DQ441419); VARV-GBR52 (DQ441447); VARV-COG70 (DQ437583); VARV-IND53 (DQ441427); VARV-BEN68 (DQ441416). Monkeypox virus: MKPV-ZAR79 (DQ011155).

Used in both figures and tables: Vaccinia virus strains: WR (AY243312); Lister-m8 (AY678276); LC16m0 (AY678277); LC16m8 (AY678275); Lister France-107 (DQ121394); Duke (DQ439815); 3737 (DQ377945); MVA (AY603355); AMVA (AY603355); MVA-1721 (DQ983236); COP (M35027); Acam3 (AY313848); TTan (AF095689). Variola virus: VARV-GAR (U18338); VARV-IND64 (DQ437585); VARV-BGD74 (DQ441422). Cowpox virus: CPXV-BR (AF482758); CPXV-GER91 (DQ437593); CPXV-GRI90 (X94355). Taterapox: TATV (NC 008291). Monkeypox virus: MKPV- LBR (DQ011156); MKPV-ZAR (NC 003310). 